Slavic Languages and Literatures 



\section{Slavic Languages and Literatures}

College of Literature, Science, and the Arts

The University of Michigan: An Encyclopedic Survey 
Copyright @ 2015 by the Regents of the University of Michigan

The University of Michigan: An Encyclopedic Survey was first published beginning in 1942. For its 2017 Bicentennial, the University undertook the most significant updating of the

Encyclopedia since the original, focusing on academic units. Entries from all versions are compiled in the Bicentennial digital and print-on-demand edition. 


\section{Contents}

1. Slavic Languages and Literatures (1975) 1 Benjamin Stolz

2. Slavic Languages and Literatures (2016) Herbert Eagle 



\section{Slavic Languages and Literatures (1975)}

\section{Benjamin Stolz}

Courses in the Russian language and Russian literature, as well as Slavic linguistics, were given between the wars by Professor Clarence L. Meader. Courses in the Polish language and Polish literature were introduced in the 1920s by Professor Tadeusz Mitana. From World War II until 1952 the Department of Russian (as it was then called) was chaired by Lidia Naumovna Pargment, who taught the advanced language and literature courses; teaching fellows were responsible for elementary instruction. In 1947 an interdepartmental M.A. program in Russian Studies was organized to supplement the existing departmental B.A. program in Russian.

The present department officially traces its beginnings to the fall of 1952, when Professor James O. Ferrell was brought here as Chairman of the newly established Department of Slavic Languages and Literatures. Under Ferrell's leadership a graduate faculty was hired and an M.A. program in Slavic Languages and Literatures was inaugurated. In 1957 Professor 
Deming Brown became Chairman; and in 1958 a Ph.D. program was instituted. From 1961 to 1971 Professor John Mersereau, Jr., served as chairman. During this "post-Sputnik" period the department expanded rapidly in faculty size, breadth of curriculum, and student enrollments. In the early 1960s, when the University was designated a Slavic Language and Area Center under the National Defense Education Act, generous infusions of federal funding were provided in the form of National Defense Foreign Language fellowships and direct salary support for department faculty. By the end of that decade, when federal funding had decreased significantly, the department had achieved its present status and had established itself as one of the leading Ph.D. programs in the field.

The department maintains a vigorous program at both the undergraduate and graduate levels. Emphasis is placed on Russian language and literature at both levels, but the department is Slavic in the broad sense, offering training in the principal non-Russian Slavic Languages (Polish, Czech, SerboCroatian, and Ukrainian) as well as in the literature and folklore of those traditions; and in Slavic linguistics. The department works with other departments and programs at the University, and has especially close ties with the Program in Comparative Literature; it plays a leading role in the Center for Russian and East European Studies, cooperating extensively in both instructional and research activities with the faculty associates from a wide range of departments who form the nucleus of the Center. 


\section{Slavic Languages and Literatures (2016)}

\section{Herbert Eagle}

In 1962, the Slavic Department established a publishing arm, Michigan Slavic Publications, with Ladislav Matějka as its general editor. During the latter part of that decade, Michigan Slavic Publications became a prominent publisher of scholarly works in Slavic languages, literatures, and cultures and in Slavic literary theory in particular. It became a leading source of the major works of Russian formalism, Czech structuralism, and Soviet semiotics, and issued seminal works in Russian and English.

In the late 1960s, John Mersereau, Irwin Titunik, and Deming Brown taught large courses in 19th- and 20th-century Russian literature in translation. Titunik also designed and taught innovative new courses in the graduate program, including a core course entitled "Movements and Genres in Russian literature."

Assya Humesky became a leader in Ukrainian and Russian language pedagogy, and designed and published textbooks in 
both. Humesky also taught the Department's courses on 19thcentury Russian poetry and on Russian drama. Mersereau, Brown, Titunik, and Horace Dewey (the Department's leading expert in medieval Russian literature) published highly respected books and articles covering Russian literature from its earliest centuries to the most recent publications of the 1960s and 1970s, while David Welsh made major contributions to the study of Polish literature, both as a scholar and as a literary translator. Particularly notable were Titunik's work on 18thcentury Russian literature, Mersereau's on Russian romanticism, and Brown's on contemporary Russian poetry and prose, particularly on the work of dissident writers. Benjamin Stolz joined the Department in the mid-1960s and expanded its offerings in Slavic linguistics and in the history and structure of the Russian and Serbo-Croatian literary languages. Stolz also produced important work on standardization in the Slavic languages and on Serbo-Croatian folklore. Mark Suino, an expert in Russian versification, also joined the Department in the mid-1960s. He became an important contributor, along with Matějka, Titunik and several graduate students, to the Michigan Slavic Publications project of translating major works of Russian formalism and Czech structuralism into English.

Stolz became chair of the Department in 1971. He served until 1986, when Mersereau returned for another term (1986-89), then was chair again from 1989 to 1991. Carl Proffer, a leading scholar of Russian literature, joined the Department in the early 1970s; he and Stolz were instrumental in bringing one of Russia's greatest 20th-century poets, Joseph Brodsky, to the University of Michigan in 1972. Brodsky was being threatened with arrest when Proffer and Stolz arranged to bring him to Michigan, first as poet-in-residence and then as a faculty member in Russian literature. Brodsky taught at Michigan for a decade; he later won the Nobel Prize for literature (in 1987) and served as U.S. poet laureate (1991-92). Brodsky gave the commencement address at the University in 1988, when he was awarded an honorary doctorate.

Stolz also succeeded in bringing other outstanding scholars and teachers to the Department and the University, including Ronald Suny and Kevork Bardakjian in Armenian Studies; 
Herbert Eagle in Russian and East European Cinema; Michael Makin and Omry Ronen in Russian literature; Vitaly Sheveroshkin in Russian and Indo-European linguistics; Bogdana Carpenter in Polish literature; and Jindřich Toman in Slavic linguistics and Czech literature and culture. The teaching of Russian language courses remained strong under the able leadership of lecturers Natalia Fischer, Natalie Challis, and Serge Shishkoff. Under Stolz's leadership, the Department became one of the strongest Slavic departments in the country.

In 1972, Proffer and his wife Ellendea Proffer founded Ann Arbor-based Ardis Publishers, which became a leading publisher of works that had been suppressed or banned in the former Soviet Union. The enterprise issued works in the original Russian and in translation. Because copies of Ardis books were often smuggled back into the Soviet Union, Ardis became a significant cultural presence in Russia.

In 1982, Matějka founded the journal Cross Currents: A Yearbook of Central European Culture, which was published by Michigan Slavic Publications for more than a decade. This journal became a leading outlet for the literary works and essays of the leading Czech, Polish, Hungarian, and Yugoslav dissident authors of the 1980s (whose work was frequently banned in their home countries), as well as for scholarly work about Central European literature, cinema, and culture. During that same decade, Bogdana Carpenter was instrumental in building the University's Copernicus Endowment for Polish Studies, which was founded in 1973. The Endowment sponsored annual lectures and established a forum for Poland's leading philosophers, artists, scholars, and political thinkers, including the Nobel Laureate for Literature Czeslaw Milosz; the great Polish poets Stanislaw Baranczak and Adam Zagajewski; the renowned philosopher Leszek Kolakowski; the avant-garde artist Zbigniew Libera; the innovative composers Krzysztof Penderecki and Henryk Gorecki; political dissidents and activists Jacek Kuron, Adam Michnik, and Bronislaw Geremek; political scientist and former U.S. national security advisor Zbigniew Brzezinski; Aleksander Kwasniewski, the former president of Poland; Krzysztof Zanussi and Agnieszka Holland, two of Poland's leading filmmakers of the 1970s through the 
2010s; and many other distinguished scholars and scientists from a variety of disciplines.

Bogdana Carpenter became chair of the Department in 1991. Carpenter was instrumental in designing and promoting new courses on central European culture, Slavic folklore, and contemporary Russian society and culture that would become mainstays of the Department for decades to come. She published seminal work on the poetic avant-garde in Poland and on the great contemporary Polish poet Zbigniew Herbert. With her husband, John Carpenter, she translated several volumes of Herbert's poetry and essays into English. Carpenter was also acclaimed for her work on the history of Polish poetry, and she edited an anthology of Polish literature in the original and in translation that became a mainstay of Polish literature courses across the continent.

In October 1992, the Department celebrated its fortieth anniversary at a gathering attended by more than fifty of its faculty, former graduate students, and friends. Among the large number of former graduate students in attendance, many had become faculty members at other colleges and universities. Joseph Brodsky gave a public poetry reading, and several faculty and former students delivered brief commemorative remarks.

In the fall of 1993, Nysusya Milman was appointed coordinator of the Russian language program within the Department. Milman organized, in October of that year, a three-day symposium on the writings of the prominent Russian prose writer and playwright Ludmila Petrushevskaya. Petrushevskaya attended the symposium and read from her works at the Rackham Amphitheater. Later that month the eminent 20th-century Polish poet and Nobel Laureate Czeslaw Milosz read from his works at Rackham.

In January 1994, the Department co-sponsored, with the University Musical Society and the Center for Russian and East European Studies, an international conference on the Russian composer Dmitri Shostakovich. Rosamund Bartlett was the key organizer. In March and April of that year, the Russian poet and literary critic Mikhail Aizenberg taught a mini-course on contemporary Russian literature and gave a reading of his own verse. 
During Carpenter's first term as chair, the Department was awarded a Graduate Assistance in Areas of National Need grant in a national competition that provided a number of graduate fellowships to entering students over the next three years.

In 1995, Jindrich Toman became chair of the Department; he would lead it ably for more than a decade. That fall, Andreas Schonle, a specialist on Russian 18th- and 19th-century Russian literature, joined the Department and became a mainstay.

In 1996, the Department held a commemorative evening and a three-day symposium in honor and in memory of its dear friend and former colleague, the poet Joseph Brodsky, who had died in January of that year. The symposium featured presentations by major scholars of Russian verse from the U.S. and abroad and an extensive exhibition of Brodsky's published works, manuscripts, and other materials at the Rackham Graduate library.

Jindřich Toman-along with Bogdana Carpenter, who returned for brief periods as chair in 1998-99 and in 2006-put the Slavic Department firmly on the map as a site for scholarship on Czech and Polish literature. These two scholars, through their research, teaching, and course development, were key innovators in strengthening the Department's commitment to the study of Slavic languages and cultures other than Russian, and in instituting minors in both Polish and Czech language, literature, and culture. In 2000, Toman launched Michigan's Czech Studies Workshop, which for a decade brought to the campus junior scholars from all over the world (those who were working on Czech culture in various disciplines, including literature, history of art, architecture, history, theater, and musicology) to share their work. This intellectual crossfertilization proved to be critical in inspiring further research and fostering a generation of specialists on Czech culture who now hold professorships in many leading research universities, including Harvard, Northwestern, Rutgers, Illinois, and North Carolina. The Czech Studies Workshop became a selfsustaining annual national symposium hosted, in turn, by members of the participating consortium of universities.

During his term as chair, Toman added two established scholars from Russia who would play major roles in future 
decades: Olga Maiorova, a leading expert on 19th-century Russian literature and intellectual history; and Mikhail Krutikov, a scholar of Russian and Yiddish literature, who was hired jointly with the Program in Judaic Studies. Both became important mentors for graduate students who would serve as graduate advisors. Andrew Herscher, another interdisciplinary scholar who worked on architecture and cultural studies with emphasis on the former Czechoslovakia and the former Yugoslavia, joined the Department as a joint appointee with the College of Architecture and Urban Planning.

In 2006, Bogdana Carpenter designed and proposed a major in Polish language, literature, and culture, one of only a few such majors in the nation. To support the Department's new majors, Eagle launched new courses in Polish cinema and in Czech New Wave cinema to augment the courses in literature and other arts offered by Carpenter and Toman. Through the excellent work of these faculty members and a group of dedicated lecturers in Ukrainian, Czech, Polish, and Bosnian-Croatian-Serbian languages (Svitlana Rogovyk, Zdenka Brodska, Ewa Pasek, Piotr Westwalewicz, and Marija Rosic), the various language curricula succeeded in serving the interests and needs of undergraduate and graduate students. The Russian program also remained strong under the pedagogical guidance of Rogovyk as language coordinator and the work of lecturers Nina Shkolnik and Alina Makin. Shkolnik taught special courses for students who came to the University with some conversational ability in Russian, and enriched the third- and fourth-year curricula with such activities as the annual presentation by students of a scene from a play in Russian. Alina Makin ably developed the intensive sequence of Russian courses in the Residential College (two semester-long courses covering material that normally took two years) and introduced a seminar taught entirely in Russian. During the same decade, Piotr Westwalewicz developed and taught several popular mini-courses on Polish avant-garde art and poetry and on the influence of rock and roll music on young Poles during the decades of struggle with an authoritarian Communist regime.

Eagle became chair of the Department in January 2006. In his first two years, he hired three new faculty members: Tatjana 
Aleksic in Bosnian-Croatian-Serbian and modern Greek literature; Benjamin Paloff in Polish, Russian, and Czech literature; and Sofya Khagi in Russian literature. Over the next several years, Aleksic became the primary mentor for graduate students working in South Slavic and Balkan languages and culture; Khagi took over key courses on 18th- and 19th-century Russian literature and played an increasingly important role in mentoring graduate students in Russian literature; and Paloff took over the leadership of the graduate program in Polish after the retirement of Bogdana Carpenter. (Carpenter became professor emerita and continued for many years to teach the course on Central European culture that she had helped to design.) Aleksic and Paloff were joint appointees with the University's Department of Comparative Literature, where they offered important courses on literary theory, translation, and topics involving cultural cross-fertilization. Khagi, Aleksic, and Paloff introduced an important graduate course on Slavic literary theories from the late 19th century through the formalist, structuralist, and post-structuralist decades of the 20th century. Aleksic and Paloff also participated with Eagle and Krutikov in another graduate course on dissident cinema in Eastern Europe.

In 2007, Alina Makin developed a service-learning course that became known by its acronym RUSLAN (Russian Service Learning in Action Network). This course enabled students to strengthen their Russian language skills while providing community service through local organizations that helped Russian-speaking immigrants, particularly senior citizens, with such tasks as preparing for U.S. citizenship and mastering use of the internet. RUSLAN became a building block for a new track in the Russian major that emphasized actual work with Russian in the real world.

Another extremely important development was the introduction of an alternative spring break learning experience in Russia's far northwest, in the provincial town of Vytegra. Michael Makin and Alina Makin organized a nine-day program involving work at the local museum and tutoring English in the local schools, enabling Michigan students to use their Russianlanguage skills to interact with a variety of Russian citizens from 
educators to high school students. Some Michigan undergraduates and graduates also were able to carry out small research projects on linguistic as well as political issues. Makin designed a pre-trip mini-course on the Russian provinces that became very popular, and the Alternative Spring Break experience enriched the education of ten to twelve undergraduates and graduate students each year.

Under Eagle's leadership, from 2006 through 2015, the Department's Ph.D. program in Slavic languages, literatures and cultures was substantially redesigned. The new plan enabled graduate students to make Slavic languages other than Russian their focus; to do cross-cultural work involving two or more East European and Eurasian cultures; and to incorporate substantial elements from other disciplines into their courses of study. This new orientation proved extremely attractive to prospective graduate students. The numbers of students applying and accepting admission to the program increased markedly over the its first few years. Courses of study combined Russian language and literature with Polish, Czech, Serbian, Croatian, Ukrainian, or Central Asian languages and literature, and featured such disciplinary combinations as literature and legal history, poetry and photography, avant-garde poetic and visual art, women's art and politics, and folklore and musicology.

Growth of the graduate program was also facilitated by the excellence of the students themselves, who won many fellowships both in external competitions and internally, for the study of languages and to support their own research.

Major books were published during this period by Ronen, Makin, Toman, Maiorova, Kruitkov, Herscher, Aleksic, and Khagi-further evidence of the Department of Slavic Languages and Literature's important place in the field. 